\title{
Aspek-Aspek Prioritas Manajemen Wakaf di Indonesia
}

\author{
Khalifah Muhamad Ali \\ Departemen Ilmu Ekonomi Syariah FEM IPB \\ khalifabma@apps.ipb.ac.id
}

\section{Meida Yuliani}

Departemen Ilmu Ekonomi Syariah FEM IPB

meida.yuliani@gmail.com

\section{Sri Mulatsih}

Departemen Ilmu Ekonomi FEM IPB

\author{
Zaki Abdullah \\ Departemen Ilmu Ekonomi Syariah FEM IPB \\ zakieksyar50@apps.ipb.ac.id
}

\begin{abstract}
One of the most potential Islamic economic instruments in Indonesia to improve the quality of people's welfare is waqf. This is supported by the demographic condition of Indonesia which majority is Muslim with big potential of waqf. Practically, the optimization of the potential is not yet in maximum condition and productive. The priority analysis of problems, solutions and strategies in waqf management in Indonesia is done in this research in order to maximize priority to made waqf management is more productive. This study uses primary and secondary data using Analytical Network Process (ANP) method. The result of the analysis shows that the lack of competence and lack of nazhir professionalism become the priority of the internal waqf management problem. While the priority of external problems is the lack of society understanding about waqf and also regulations that are less supportive. Improving the competence, guidance and mentoring of nazhir becomes the priority of internal solutions, while the priority of external solution is the optimization of the role of Badan Wakaf Indonesia (BWI) by improve the regulation by looking at the reality. Short term priority strategy that can be done is to socialize and educate about waqf to all elements.
\end{abstract}

Keywords: ANP, management waqf, strategy, waqf

\begin{abstract}
Abstrak
Salah satu instrumen ekonomi Islam yang sangat potensial di Indonesia untuk meningkatkan kualitas kesejahteraan masyarakat adalah wakaf. Hal ini didukung dengan kondisi demografi Indonesia yang mayoritas adalah muslim dengan potensi wakaf yang besar. Dalam praktiknya, optimalisasi potensi belum dalam kondisi maksimal dan
\end{abstract}

Al Falah: Journal of Islamic Economics, Vol. 3, No. 1, 2018

STAIN Curup|E-ISSN: 2548-3102, P-ISSN: 2548-2343

Available online: http://journal.staincurup.ac.id/index.php/alfalah 
produktif. Analisis prioritas masalah, solusi dan strategi dalam manajemen pengelolaan wakaf di Indonesia dilakukan dalam penelitian ini agar dapat memaksimalkan prioritas supaya pengelolaan wakaf lebih produktif. Penelitian ini menggunakan data primer dan sekunder dengan menggunakan metode Analytical Network Process (ANP). Hasil analisis menunjukkan bahwa rendahnya kompetensi dan kurangnya profesionalisme nazhir menjadi prioritas masalah internal pengelola wakaf. Sedangkan yang menjadi prioritas masalah eksternal adalah kurangnya pemahaman para wakif mengenai wakaf ditambah regulasi yang kurang mendukung. Meningkatkan kompetensi, pembinaan dan pendampingan nazhir menjadi prioritas solusi dari internal, sedangkan prioritas solusi eksternal adalah optimalisasi peran Badan Wakaf Indonesia (BWI) dengan melakukan revisi regulasi dengan melihat realita yang ada. Strategi prioritas jangka pendek yang dapat dilakukan adalah melakukan sosialisasi dan edukasi mengenai wakaf terhadap semua elemen.

Kata Kunci: $A N P$, pengelolaan wakaf, strategi, wakaf

\section{PENDAHULUAN}

Salah satu instrumen terpenting dan potensial dalam ekonomi Islam adalah wakaf. Wakaf adalah amalan yang bersifat multidimensi. Selain ibadah, wakaf juga merupakan muamalah yang memiliki fungsi penting dalam menunjang kesejahteraan masyarakat.

Dalam sejarah Islam, wakaf telah berperan sangat penting untuk pengembangan kegiatan-kegiatan sosial, ekonomi dan kebudayaan masyarakat serta telah banyak memfasilitasi para sarjana dan mahasiswa dengan sarana dan prasarana yang memadai untuk melakukan riset dan menyelesaikan studi mereka. Berbagai program didanai dari hasil wakaf seperti penulisan buku, penerjemahan, dan kegiatan-kegiatan ilmiah dalam berbagai bidang termasuk kesehatan. Wakaf tidak hanya mendukung pengembangan ilmu pengetahuan, tetapi juga menyediakan berbagai fasilitas yang diperlukan mahasiswa maupun masyarakat. ${ }^{1}$

Mayoritas penduduk muslim di Indonesia ditambah dengan wilayah yang luas, menyimpan potensi wakaf yang sangat besar. Namun, potensi tersebut belum dikelola secara optimal. Berdasarkan data yang diperoleh dari Kementerian Agama RI tahun 2017, aset tanah wakaf di Indonesia seluas 47 643.03 Ha yang tersebar di 317135 lokasi dengan total wakaf yang sudah bersertifikat sebanyak 64.91\%. Penggunaan tanah wakaf tersebut sebagian besar masih berupa wakaf langsung (konsumtif), sebagaimana dapat dilihat pada

${ }^{1}$ Hasanah, Potensi Wakaf Uang untuk Pembangunan Perumahan Rakyat, (Jakarta: BWI Indonesia, 2010) h. 34-35 
Gambar 1 yang menunjukkan penggunaan tanah wakaf didominasi untuk pembangunan masjid sebesar $45.05 \%$ dan musholla sebesar $28.50 \%$. $^{2}$

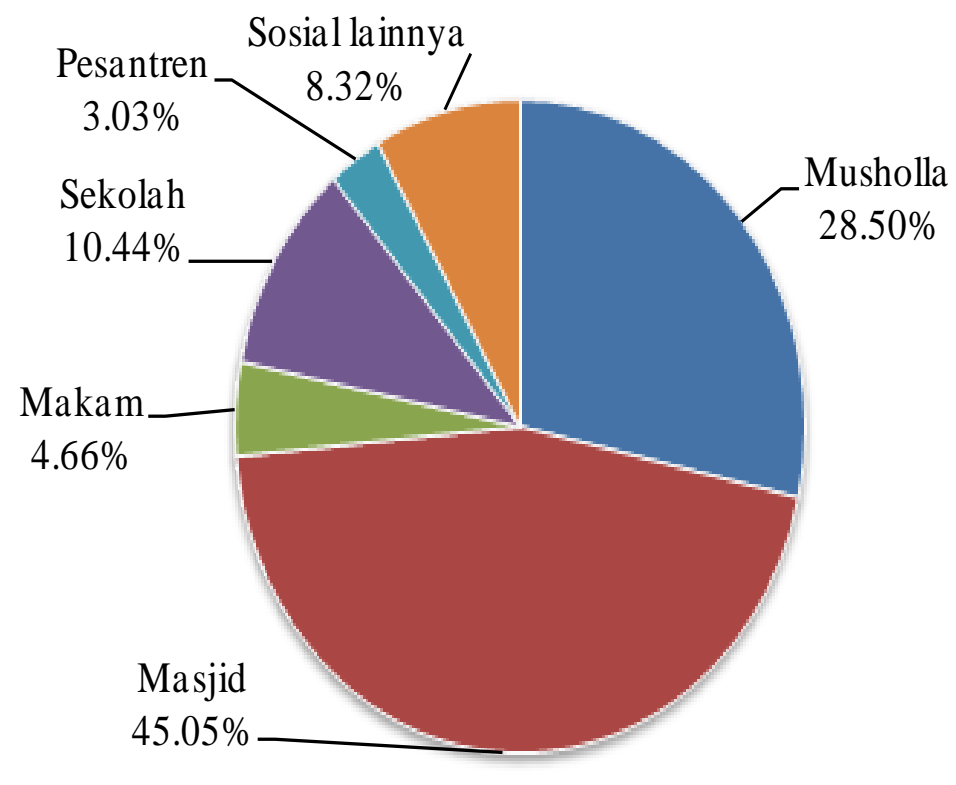

Sumber : SIWAK (2017)

Gambar 1 Persentase penggunaan tanah wakaf di Indonesia

Hal ini didukung dengan penelitian Pusat Bahasa dan Budaya UIN Jakarta tahun 2006 yang dilakukan terhadap 500 responden nazbir (pengelola wakaf) di Indonesia. Penelitian tersebut menunjukkan bahwa harta wakaf yang bersifat diam sebesar 77\%, dan yang dikelola produktif hanya sebesar 33\%. ${ }^{3}$

Potensi yang dijelaskan di atas belum termasuk potensi wakaf benda bergerak seperti wakaf uang. Potensi wakaf uang di Indonesia mencapai 3 triliun per tahun dengan perkiraan jumlah umat muslim yang dermawan sebesar 10 juta jiwa dan rata-rata penghasilan per bulan sebesar Rp 500000 hingga Rp 10000 000 seperti terlihat pada Tabel 1. Dana ini akan terus bertambah jika diserahkan

2 [SIWAK] Sistem Informasi Wakaf, Data Penggunaan Tanah Wakaf Indonesia, http://siwak.kemenag.go.id, diakses pada 26 Desember 2017, pukul 20.00 WIB

${ }^{3}$ Najib TA, al-Makassary, Wakaf, Tuhan, dan Agenda Kemanusiaan, (Jakarta: Center for the Study of Religion and Culture (CSRC), 2006) h. 84 
4 |Al-Falah: Journal of Islamic Economics, Vol.3, No.1, 2018

kepada pengelola yang profesional dan diinvestasikan di sektor yang produktif, ia akan menjadi sumber dana yang luar biasa besar bagi umat Islam. ${ }^{4}$

Tabel 1 Potensi wakaf uang

\begin{tabular}{ccccc}
\hline $\begin{array}{c}\text { Tingkat } \\
\text { Penghasilan/Bulan } \\
(\mathbf{R p})\end{array}$ & $\begin{array}{c}\text { Jumlah } \\
\text { Muslim } \\
\text { (Jiwa) }\end{array}$ & $\begin{array}{c}\text { Tarif } \\
\text { Wakaf/Bulan } \\
\text { (Rp) }\end{array}$ & $\begin{array}{c}\text { Potensi } \\
\text { Wakaf } \\
\text { Uang/Bulan } \\
\text { (Rp) }\end{array}$ & $\begin{array}{c}\text { Potensi Wakaf } \\
\text { Uang/Tahun } \\
\text { (Rp) }\end{array}$ \\
\hline $\mathbf{5 0 0 ~ 0 0 0}$ & 4 juta & 5000 & 20 milyar & 240 milyar \\
$\mathbf{1 - 2}$ juta & 3 juta & 10000 & 30 milyar & 360 milyar \\
$\mathbf{2 - 5}$ juta & 2 juta & 50000 & 100 milyar & 1.2 triliun \\
$\mathbf{5 - 1 0 ~ j u t a}$ & 1 juta & 100000 & 100 milyar & 1.2 triliun \\
\hline Total & & & & $\mathbf{3}$ triliun
\end{tabular}

Sumber : Nasution dan Hasanah (2005)

Jika dibandingkan dengan negara-negara lain, maka perkembangan wakaf di Indonesia masih tertinggal sebagaimana ditunjukkan pada Tabel 2. Pemanfaatan dana wakaf di Indonesia baru mencapai $2 \%$, perbedaannya sangat signifikan dengan pemanfaatan dana wakaf Singapura yang mencapai $92 \%$, padahal jumlah penduduk muslim dan luas wilayahnya tidak sebanding dengan Indonesia. Sebagai negara dengan jumlah penduduk muslim paling besar seharusnya dana wakaf yang berhasil dihimpun juga besar, tetapi realitanya masih sangat kecil.

Tabel 2 Pemanfaatan dana wakaf di beberapa negara

\begin{tabular}{l|c}
\multicolumn{1}{c|}{ Negara } & Presentase (\%) \\
\hline Singapura (Lokal) & 92 \\
\hline Saudi Arabia & 4 \\
\hline India & 2 \\
\hline Indonesia & 2 \\
\hline Total & $\mathbf{1 0 0}$ \\
& Sumber : Karim (2007)
\end{tabular}

${ }^{4}$ Nasution ME, Hasanah U, Wakaf Tunai Inovasi Finansial Islam, Peluang dan dalam Mewijudkan Kesejahteraan Umat, (Jakarta: PKT'TI-UI, 2005) h. 37 
Wakaf yang ada di Indonesia dikelola oleh naz̧bir yang dibagi menjadi tiga kategori yaitu nazhir perorangan, nąhir organisasi, dan nąhir badan hukum. Peran nazhir dalam pengelolaan wakaf menjadi faktor yang sangat penting bagi berkembang atau tidaknya suatu wakaf. Nazhir adalah orang yang paling bertanggung jawab terhadap harta wakaf yang dipegangnya, baik terhadap harta wakaf itu sendiri maupun terhadap hasil dan upaya-upaya pengembangannya. Setiap kegiatan nazhir terhadap harta wakaf harus dalam pertimbangan kesinambungan harta wakaf untuk mengalirkan manfaatnya bagi kepentingan manquf 'alaib atau penerima wakaf.'

Masih banyak masalah-masalah yang dihadapi dalam pengelolaan tanahtanah wakaf secara produktif di Kabupaten Bandung, di antaranya sebagian besar tanah wakaf digunakan untuk sarana ibadah dan sebagian lagi letaknya tidak strategis. Selain itu, pengetahuan dan pemahaman nazhir terhadap peraturan perwakafan masih kurang. ${ }^{6}$

Prioritas masalah dari aspek masyarakat adalah rendahnya kesadaran masyarakat untuk berwakaf dan rendahnya pemahaman masyarakat tentang perwakafan. Prioritas masalah dari aspek pengelola adalah rendahnya biaya operasional dan lemahnya sumber daya nazhir. Prioritas masalah pemerintah adalah kurangnya sosialisasi Undang-Undang Perwakafan dan rendahnya biaya APBN untuk sertifikasi tanah wakaf. Prioritas solusi atas permasalahan dari aspek masyarakat adalah sosialisasi dan edukasi kepada masyarakat serta pendekatan dari sisi agama. Prioritas solusi atas permasalahan dari aspek pengelola adalah peningkatan biaya operasional dan training serta perbaikan sistem rekrutmen nazhir. Prioritas solusi atas permasalahan wakaf dari aspek pemerintah adalah peningkatan sosialisasi Undang-Undang Perwakafan dan peningkatan biaya APBN sertifikasi tanah wakaf. ${ }^{7}$

Di daerah Sumatera Barat (Sumbar) aspek paling bermasalah dalam pengelolaan wakaf adalah nazhir, sedangkan di Riau aspek paling bermasalah adalah wakif. Permasalahan nazhir yang paling utama di Sumbar adalah nazbir bukan sebagai profesi utama, sementara di Riau adalah rendahnya kompetensi nazhir dalam mengelola wakaf. Prioritas permasalahan wakif di Riau adalah pemberian wakaf secara langsung kepada personal, sementara di Sumbar adalah

5 Aziz M, “Kompetensi Ną̧bir dalam Mengelola Wakaf Produktif'. Jurnal AlAwqaf, Vol. 7, No. 1 (2014). h. 60

${ }^{6}$ Fathurrohman T, Wakaf dan Penanggulangan Kemiskinan Tinjauan Hukum Islam Peraturan Perundang-undangan di Indonesia (Studi Kasus Pengelolaan Wakaf di Kabupaten Bandung), (Jakarta: Universitas Indonesia, 2012). h. 44

7 Wadud AMA, Solusi Permasalahan Wakaf Produktif di Indonesia Pendekatan Modifikasi Analytic Network Process, (Depok: Universitas Indonesia, 2013) h. 53 
wakif tidak koordinasi dengan ahli waris. Prioritas masalah di Sumbar dan Riau dari aspek regulator adalah sosialisasi UU yang masih kurang. Prioritas solusi terhadap masalah sosialisasi UU yang masih kurang di Sumbar adalah optimalisasi melalui media online, sedangkan di Riau adalah pembuatan buletin wakaf. Prioritas solusi aspek nazhir di Sumbar adalah meningkatkan insentif nazhir, sedangkan di Riau adalah pelatihan intensif bagi nazhir. Prioritas solusi aspek wakif sebagai aspek prioritas masalah di Riau adalah kemudahan mendapatkan informasi mengenai wakif, sedangkan di Sumbar dengan adanya koordinasi antara nazhir dengan ahli waris dalam pemberian wakaf. ${ }^{8}$

Pembinaan terhadap nąhir wakaf yang merupakan implementasi dari Pasal 13 UU No.41 Tahun 2004 tentang wakaf sudah dilaksanakan oleh Kementerian Agama Kota Padang dan BWI Sumatera Barat akan tetapi belum efektif. Dampak dari adanya pembinaan ini diantaranya, nąhir telah menjalankan tugasnya yang tercantum dalam pasal 11 UU No.41 Tahun 2004 tentang wakaf. Kendala atau hambatan yang dihadapi dalam pembinaan dikarenakan beberapa faktor, yakni faktor penegak hukum tidak mendata dengan baik nąhir wakaf sehingga ketika ada pembinaan banyak ną̧bir yang tidak diikutsertakan. Faktor sarana dan fasilitas yakni dana atau anggaran yang minim dalam melaksanakan pembinaan, serta dari faktor kebudayaan yang masih berkembang yakni ikrar wakaf yang hanya diucapkan secara lisan tanpa adanya ikrar di depan Pejabat Pembuat Akta Ikrar Wakaf (PPAIW).

Perbedaan penelitian ini dengan penelitian-penelitian terdahulu di bidang wakaf adalah penelitian ini dilakukan dengan metode ANP dengan pendekatan aspek masalah, solusi, dan strategi sehingga lebih melihat kondisi riil dan menerapkan hasil analisis dalam bentuk kebijakan dan strategi-strategi prioritas yang dapat diterapkan dalam tenggat antar waktu tertentu dalam upaya optimalisasi pengelolaan wakaf agar menjadi lebih produktif.

Berdasarkan latar belakang tersebut, maka permasalahan dari penelitian ini adalah sebagai berikut:

1. Apa saja prioritas permasalahan yang menyebabkan pengelolaan wakaf di Indonesia belum produktif?

8 Huda N, Anggraini D, Rini N, Hudori, Mardoni Y, “Akuntabilitas sebagai Solusi Pengelolaan Wakaf'. Jurnal Akuntansi Multiparadigma, Vol. 5, No. 3 (2014) h. 485-497.

9 Putri KS, Pembinaan Nazhir Wakaf di Kementerian Agama Kota Padang dan Badan Wakaf Indonesia Sumatera Barat (Studi Implementasi Pasal 13 Undang-Undang No.41 Tabun 2004 Tentang Wakaf, (Yogyakarta: UIN Sunan Kalijaga, 2016). 
2. Bagaimana solusi dan strategi untuk meningkatkan pengelolaan wakaf di Indonesia supaya lebih produktif?

Penelitian ini dilakukan melalui wawancara dengan beberapa pakar dan praktisi di institusi dan organisasi pengelola wakaf di Indonesia. Penelitian ini dilakukan pada bulan Maret hingga Mei 2017.

Data yang digunakan dalam penelitian adalah data primer dan data sekunder. Data primer diperoleh dari hasil wawancara dan pengisian kuesioner terhadap para pakar dan praktisi yang memahami bidang wakaf. Data sekunder diperoleh dari dokumen, literatur, dan jurnal ilmiah yang relevan dengan penelitian.

Metode penelitian ini yaitu Analytical Network Process (ANP) dimana dilakukan kuantifikasi model dari analisis kualitatif yang didapatkan dari responden yang berjumlah tujuh orang expert dalam bidang wakaf. Dalam metode ANP jumlah sampel/responden tidak digunakan sebagai patokan validitas. $^{10}$

Tujuan yang diharapkan berdasarkan permasalahan yang ada adalah sebagai berikut:

1. Menganalisis permasalahan prioritas yang menyebabkan pengelolaan wakaf di Indonesia belum produktif.

2. Menganalisis solusi dan strategi prioritas untuk meningkatkan pengelolaan wakaf di Indonesia supaya lebih produktif.

\section{HASIL DAN PEMBAHASAN}

\section{Hasil Penelitian dengan Model Analytic Network Process (ANP)}

Berdasarkan hasil literatur review dan wawancara mendalam (indepth interview) kepada para pakar dan praktisi wakaf, terdapat dua masalah yang menyebabkan pengelolaan wakaf di Indonesia belum produktif, yaitu masalah internal dan masalah eksternal. Masalah internal terdiri dari lima aspek yaitu rendahnya kompetensi naz̧bir, kurangnya profesionalisme naz̧bir, mayoritas naz̧bir perorangan, kurangnya pemahaman naz̧bir tentang wakaf, dan profesi sebagai naz̧hir yang tidak begitu menarik. Masalah eksternal terdiri atas lima aspek yaitu penunjukkan nazbir oleh wakif, kurangnya pemahaman wakif, kurangnya peran dan dukungan pemerintah, regulasi yang kurang mendukung, dan minimnya biaya operasional. Sedangkan solusi untuk mengoptimalkan pengelolaan wakaf

10 Ascarya, Analytic Network Process (ANP) Pendekatan Baru Studi Kualitatif, (Jakarta: Seminar Internasional Program Magister Akuntansi Fakultas Ekonomi, 27 Januari 2005) 
agar lebih produktif terbagi menjadi dua yaitu solusi internal dan solusi eksternal. Solusi internal terdiri dari lima aspek yaitu peningkatan kompetensi nazhir, pembinaan dan pendampingan nazbir, konsolidasi antar naz̧bir, transformasi nazhir menjadi lembaga, dan meningkatkan insentif nazhir. Solusi eksternal terdiri atas lima aspek yaitu perbaikan sistem rekrutmen nazhir, sosialisasi dan edukasi kepada wakif atau calon wakif, optimalisasi fungsi dan peran BWI, revisi regulasi yang kurang mendukung, dan meningkatkan biaya operasional. Strategi yang dirumuskan berdasarkan masalah dan solusi yang ada dibagi menjadi tiga yaitu sinergi dan kolaborasi antar lembaga/instansi terkait, sosialisasi dan edukasi secara komprehensif kepada semua elemen, dan optimalisasi sumber daya yang sudah ada. Aspek-aspek tersebut menghasilkan sebuah model ANP seperti pada Gambar 2.

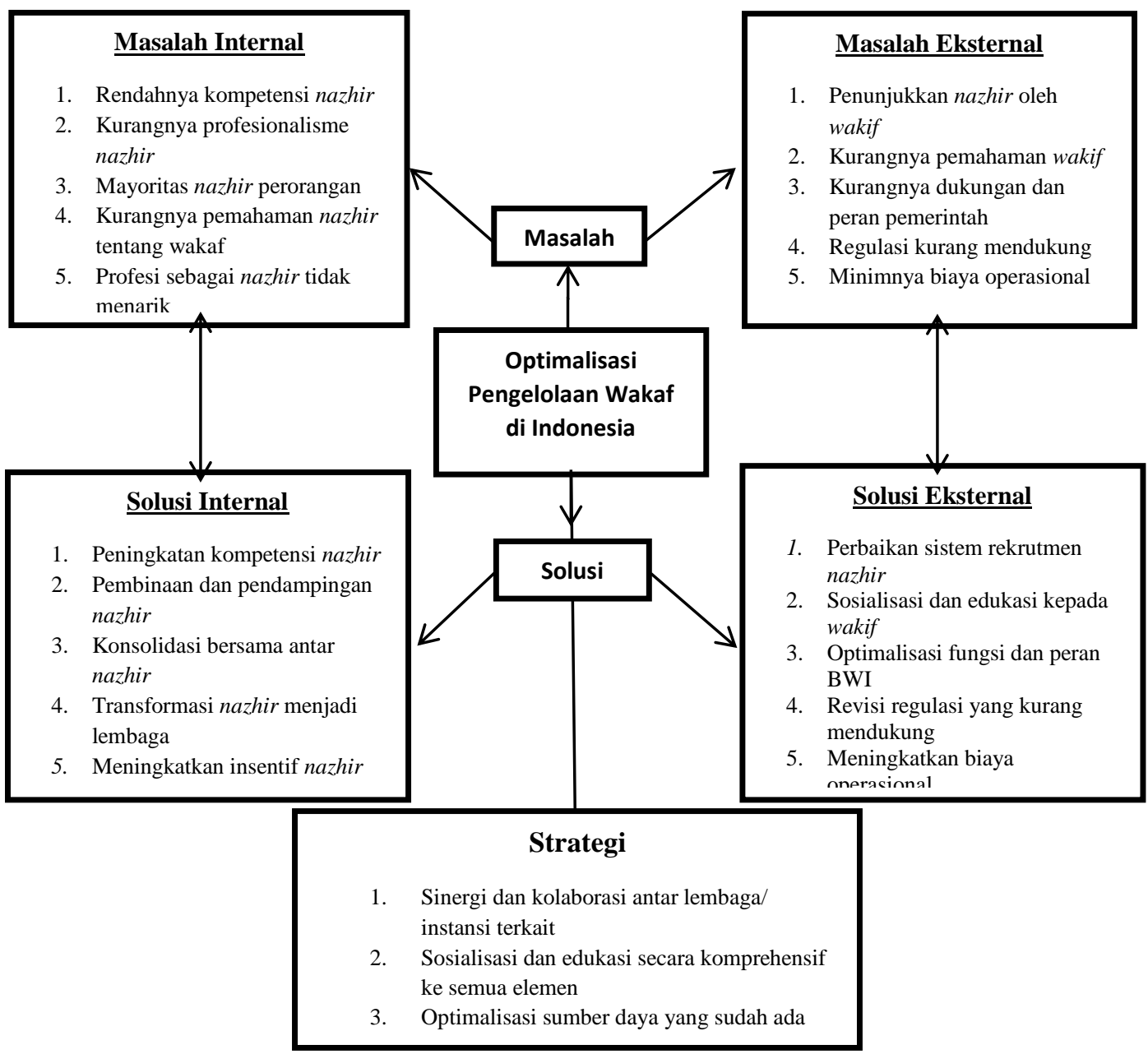

Gambar 2 Model Analytic Network Process (ANP) 


\section{Aspek Pendekatan Masalah Pengelolaan Wakaf di Indonesia}

Masalah yang menyebabkan pengelolaan wakaf di Indonesia belum produktif terbagi menjadi dua yaitu masalah internal dan masalah eksternal. Berdasarkan hasil pengolahan data, prioritas utama masalahnya adalah masalah internal dengan nilai geometric mean (GMk) sebesar 0.75, sedangkan prioritas kedua adalah masalah eksternal dengan nilai geometric mean (GMk) sebesar 0.25. Tingkat prioritas tersebut dapat dilihat pada Gambar 3. Hal tersebut menunjukkan bahwa masalah yang paling besar memengaruhi pengelolaan wakaf di Indonesia berasal dari internal, sehingga masalah internal harus mendapatkan perhatian yang lebih besar untuk dapat diatasi. Perhitungan rater agreement menghasilkan nilai Kendall's Coefficient of Concordance atau W sebesar 1 yang menunjukkan kesepakatan yang sempurna artinya seluruh responden sepakat bahwa masalah utama pengelolaan wakaf yang paling prioritas adalah masalah internal.

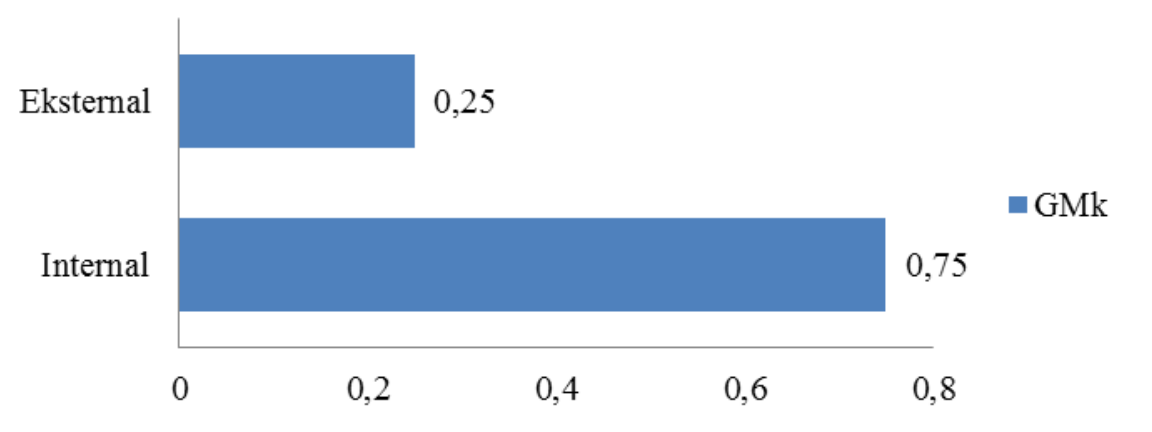

Gambar 3 Tingkat prioritas masalah

\section{Masalah Internal}

Masalah internal yang dimaksud dalam penelitian ini adalah masalah yang berasal dari dalam aspek pengelola (nazhir). Masalah internal terbagi menjadi lima yaitu rendahnya kompetensi nazhir, kurangnya profesionalisme nazbir, mayoritas nazhir perorangan, kurangnya pemahaman nazhir tentang wakaf, dan profesi sebagai nazhir yang tidak begitu menarik. Berdasarkan hasil pengolahan data, tingkat prioritas masalah internal ini dapat dilihat pada Gambar 4. Prioritas pertama yaitu rendahnya kompetensi nazhir dengan geometric mean sebesar 0.33. Prioritas kedua yaitu kurangnya profesionalisme nazhir dengan geometric mean sebesar 0.24. Prioritas ketiga yaitu kurangnya pemahaman nazhir tentang wakaf dengan geometric mean sebesar 0.18. Prioritas keempat yaitu mayoritas nazhir perorangan dengan geometric mean sebesar 0.16. Prioritas kelima yaitu profesi sebagai nazhir tidak begitu menarik dengan geometric mean sebesar 0.09. Hasil perhitungan rater agreement menghasilkan nilai Kendall's Coefficient of Concordance atau W sebesar 0.67, 
yang menunjukkan bahwa tingkat kesepakatan para pakar (responden) cukup tinggi.

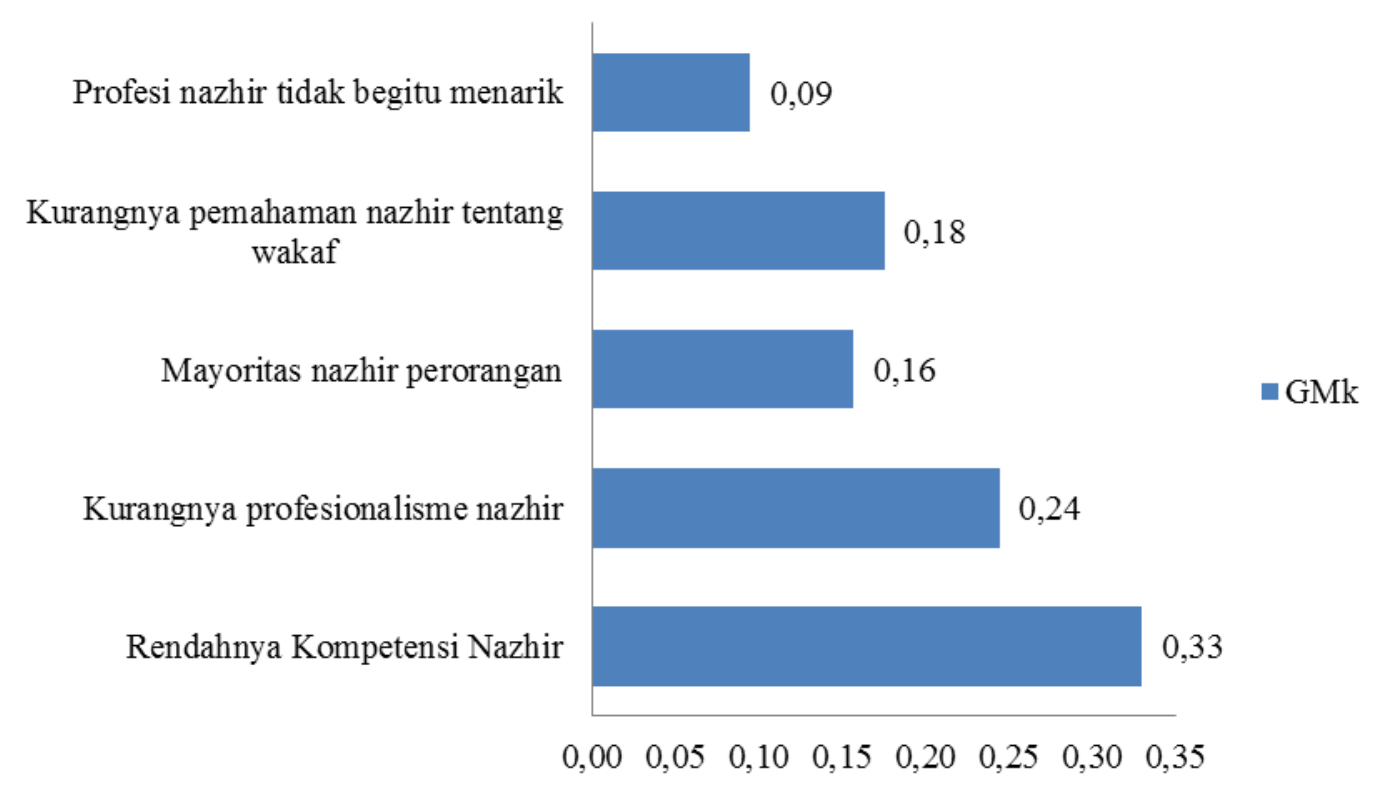

Gambar 4 Tingkat prioritas masalah internal

\section{Rendahnya Kompetensi Nazhir}

Prioritas pertama masalah internal yaitu rendahnya kompetensi ną̧ hir dengan nilai geometric mean sebesar 0.33 . Hal ini menunjukkan bahwa rendahnya kompetensi naz̧bir menjadi masalah internal yang paling besar memengaruhi pengelolaan wakaf di Indonesia.

Menurut para pakar, rendahnya kompetensi nąhir disebabkan oleh penunjukkan naz̧bir yang dilakukan wakif. Umumnya naz̧bir yang ditunjuk oleh wakif hanya berdasarkan pada hubungan kekerabatan dan kepercayaan pada tokoh agama setempat saja, bukan berdasarkan pada kompetensi yang dimilikinya. Hal tersebut menjadikan nað̧bir yang ditunjuk tidak memiliki kompetensi yang memadai dalam mengelola wakaf, sehingga wakaf bukan hanya tidak produktif bahkan bisa menjadi sumber konflik di masyarakat.

Kompetensi yang dimaksud dalam penelitian ini adalah kompetensi yang diperlukan nąhir dalam mengelola wakaf. Kompetensi tersebut terbagi menjadi dua yaitu kompetensi diniyah (agama) dan kompetensi kifayah (bisnis). ${ }^{11}$

${ }^{11}$ Aziz M, "Kompetensi Naz̧hir dalam Mengelola Wakaf Produktif'. Jurnal AlAwqaf, Vol. 7, No. 1 (2014). h. 63 
Kompetensi diniyah adalah kompetensi nazhir yang berhubungan dengan keagamaan, seperti ilmu syar'i dan pengamalannya, ditambah lagi dengan maksud institusi wakaf yaitu dalam rangka berdakwah dan menyampaikan ajaran agama Islam kepada umat manusia. Adapun kompetensi kifayah adalah kompetensi yang mengacu kepada kemampuan nazhir dalam memelihara, menjaga, melindungi, memanfaatkan, mengembangkan, menginvestasikan dan mendistribusikan hasil atau keuntungan wakaf kepada pihak-pihak yang berhak menerimanya.

Realitanya mayoritas nazhir saat ini hanya memiliki kompetensi dalam hal agama saja, namun sedikit dari mereka yang memiliki kompetensi dalam hal bisnis. Padahal kompetensi bisnis juga sangat diperlukan bagi naz̧ir, karena di dalam wakaf ada mekanisme mengelola aset.

\section{Kurangnya Profesionalisme Nazhir}

Prioritas masalah internal yang kedua yaitu kurangnya profesionalisme naz̧ir dengan nilai geometric mean sebesar 0.24. Masalah ini disebabkan oleh mayoritas nazhir yang menjadikan pekerjaannya hanya sebagai sampingan bukan menjadi pekerjaan utama. Menurut salah satu responden, umumnya nazhir sudah berumur tua dan hanya menjadikan pekerjaannya sebagai bentuk pengabdian akhirat, sehingga tidak dapat mengelola wakaf secara penuh. Survei yang dilakukan Pusat Bahasa dan Budaya (PBB) UIN Jakarta tahun 2006 terhadap 500 nąhir di 11 propinsi memperlihatkan bahwa hanya sedikit nazhir wakaf yang benar-benar mengelola wakaf secara penuh (full time) yaitu sebesar 16\%, sisanya 84\% mengakui tugasnya sebagai nazhir hanyalah pekerjaan sampingan (part time). Seorang nazhir dikatakan profesional jika nazhir tersebut melakukan pekerjaannya sesuai dengan keahlian dibidangnya, mengerahkan waktu, pikiran dan tenaga untuk pekerjaannya serta memiliki komitmen yang kuat terhadap pekerjaannya. ${ }^{12}$

Selain itu, penunjukkan nazhir oleh wakif yang berlandaskan kekerabatan atau kepercayaan pada tokoh agama juga dapat menyebabkan nazhir kurang bisa mengelola wakaf secara profesional. Salah satu responden mengatakan:

"... dalam wakaf si wakif punya hak di awal ikerar wakaf untuk menunjuk naghir. Dari dulu sampai sekarang, soal trust itu penting artinya wakif harus percaya pada nazhir. Biasanya yang dipercaya oleh wakif itu abli agama atau tokoh setempat. Konsekuensinya nazhir bukanlah seorang profesional yang seharusnya, bukan juga orang yang berkompeten, karena pemilihannya hanya dari modal kepercayaan saja. Yang kita inginkan adalah percaya boleh, tapi kepercayaan itu untuk orang-orang yang profesional. Hal ini perlu

12 Rozalinda, Manajemen Wakaf Produktif. (Jakarta: Rajawali Pers, 2015) h. 62 
diberikan sosialisasi untuk apa wakaf itu sebenarnya, karena cara berpikir wakaf produktif itu belum ada pada wakif ..."13

\section{Pemahaman Nazhir yang Kurang}

Prioritas masalah internal yang ketiga yaitu kurangnya pemahaman ną̧ir tentang wakaf dengan nilai geometric mean sebesar 0.18. Masalah ini terjadi karena kurangnya sosialisasi tentang wakaf secara komprehensif, baik mengenai fikih wakaf ataupun perundang-undangan wakaf. Hal tersebut menjadikan nazhbir pada umumnya memiliki pemahaman yang masih tradisional. Mereka memahami bahwa wakaf hanya berupa sarana ibadah atau makam. Selain itu, mayoritas nazhir wakaf di Indonesia juga menganut mazhab syafii, sehingga pemahaman fikihnya cenderung kaku dalam aspek barang-barang yang boleh diwakafkan, peruntukkan wakaf, dan pertukaran wakaf. Hal ini menyulitkan pengelolaan wakaf menuju ke arah produktif.

Sosialisasi UU wakaf yang masih kurang membuat banyak pengelola wakaf khususnya nazhir tidak paham dalam mengelola wakaf, mulai dari pengurusan sertifikat wakaf sampai kepada pengembangan harta wakaf tersebut. Akibatnya, harta wakaf yang ada selama ini menjadi tidak produktif dan membuat akuntabilitas pengelola wakaf makin rendah dan tidak mendapatkan kepercayaan masyarakat dalam mengelola wakaf. Dengan kondisi seperti ini, tanah-tanah wakaf agak sulit untuk dikelola secara produktif sesuai dengan ketentuan hukum Islam maupun ketentuan peraturan perundang-undangan yang berlaku.

\section{Mayoritas Nazhir Perorangan}

Prioritas masalah internal yang keempat yaitu mayoritas nazhir perorangan dengan nilai geometric mean sebesar 0.16. Masalah ini disebabkan oleh para wakif yang menyerahkan urusan wakafnya kepada orang-orang yang dianggap dekat atau tokoh setempat, sehingga umumnya wakaf dikelola oleh nazhir perorangan bukan lembaga. Selain itu, kepercayaan dan akses wakif terhadap nazhir lembaga yang masih rendah juga membuat para wakif lebih cenderung memilih nazhir perorangan.

Hasil survei yang dilakukan oleh Pusat Bahasa dan Budaya UIN Jakarta tahun 2006 terhadap 500 nazhir di 11 propinsi menunjukkan bahwa praktik pengelolaan wakaf umumnya dikelola nazhir perorangan sebesar 66\%, nazhir badan hukum 18\%, dan nazhir organisasi 16\%. Prioritas masalah pada wakif

${ }^{13}$ Wawancara dengan Nadratuzzaman Hosen, Wakil Ketua Dewan Pertimbangan BWI di Jakarta, 26 September 2017 
adalah budaya pemberian wakaf langsung kepada personal, sehingga wakaf kurang berkembang menjadi lebih produktif.

\section{Profesi Nazhir Kurang Diminati}

Prioritas masalah internal yang kelima yaitu profesi sebagai ną̧bir yang tidak begitu menarik dengan nilai geometric mean sebesar 0.09. Menurut salah satu responden, profesi ną̧ profesi yang menarik bagi masyarakat karena sisi finansial yang juga kurang menarik, ini mindset yang umum terjadi. Selain itu, umumnya masyarakat masih menganggap bahwa naghir hanyalah pekerjaan yang bersifat sukarela, sehingga kurang tertarik untuk terjun di dalamnya.

Hal ini sesuai dengan survei yang dilakukan oleh Pusat Bahasa dan Budaya UIN Jakarta yang menunjukkan bahwa hanya 16\% nazhir yang benar-benar mengelola wakaf secara penuh dan 84\% nazhir mengakui tugasnya hanyalah pekerjaan sampingan. Data tersebut menggambarkan bahwa profesi nazhir bukanlah profesi impian dalam masyarakat, terutama karena rendahnya imbalan (reward) sebagai nazhir. Survei juga membuktikan bahwa hanya 8\% nazhir yang mengaku mendapat imbalan. ${ }^{14}$

\section{Masalah Eksternal}

Masalah eksternal yang dimaksud dalam penelitian ini adalah masalah yang berasal dari luar aspek pengelola (nazhir) yang menyebabkan pengelolaan wakaf di Indonesia belum optimal. Masalah ini terbagi menjadi lima yaitu penunjukkan nazhir oleh wakif, kurangnya pemahaman wakif, kurangnya peran dan dukungan pemerintah, regulasi yang kurang mendukung, dan minimnya biaya operasional. Berdasarkan hasil pengolahan data, prioritas masalah eksternal yang utama yaitu kurangnya pemahaman wakif dengan nilai geometric mean sebesar 0.25. Prioritas kedua yaitu regulasi yang kurang mendukung dengan geometric mean sebesar 0.247. Prioritas ketiga yaitu kurangnya peran dan dukungan pemerintah dengan geometric mean sebesar 0.209. Prioritas keempat yaitu penunjukkan nazbir oleh wakif dengan geometric mean sebesar 0.183. Prioritas kelima yaitu minimnya biaya operasional dengan geometric mean sebesar 0.111. Gambar 5 menunjukkan tingkat prioritas dari masalah eksternal tersebut. Hasil perhitungan rater agreement menghasilkan nilai Kendall's Coefficient of Concordance atau W sebesar 0.37, yang menunjukkan bahwa tingkat kesepakatan para pakar (responden) cukup beragam atau bervariatif.

${ }^{14}$ Najib TA, al-Makassary, Wakaf, Tuhan, dan Agenda Kemanusiaan, (Jakarta: Center for the Study of Religion and Culture (CSRC), 2006) h. 30 


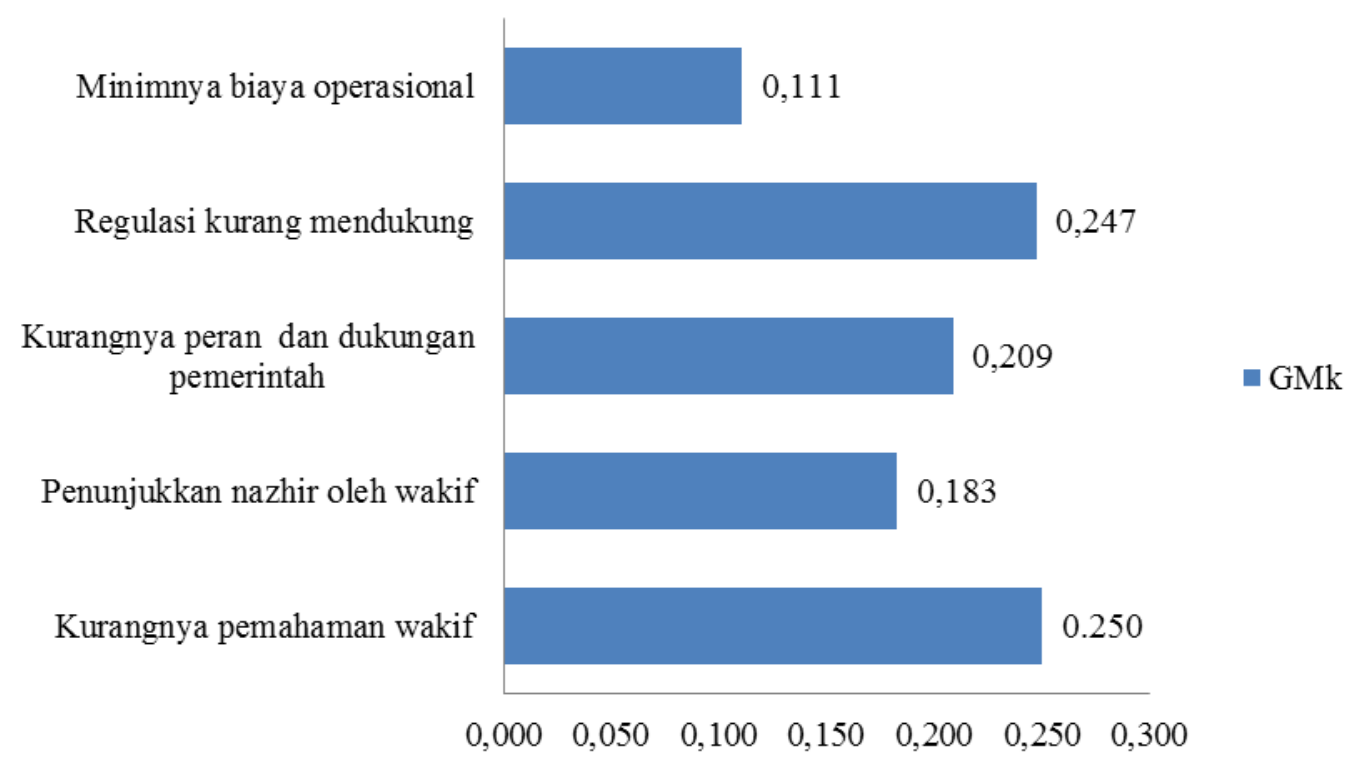

Gambar 5 Tingkat prioritas masalah eksternal

\section{Pemahaman Wakif yang Kurang}

Prioritas masalah eksternal yang pertama yaitu kurangnya pemahaman wakif dengan nilai geometric mean sebesar 0.25 . Hal ini menunjukkan bahwa kurangnya pemahaman wakif menjadi masalah eksternal yang paling besar pengaruhnya terhadap pengelolaan wakaf di Indonesia.

Masalah ini disebabkan oleh kurangnya sosialisasi tentang wakaf secara komprehensif, baik tentang peraturan wakaf dalam Islam maupun perundangundangan. Kurangnya sosialisasi tersebut menjadikan pemahaman wakif mengenai wakaf masih cenderung tradisional dan belum memiliki pola pikir wakaf yang produktif, sehingga mayoritas wakaf yang diberikan hanya berupa wakaf langsung bukan wakaf produktif.

Menurut responden, sampai saat ini masih ditemukan wakif yang menganggap bahwa harta yang ia wakafkan masih miliknya dan pada akhirnya diberikan pada ahli waris, sehingga wakaf tersebut tidak bisa lagi dikelola oleh nashir untuk kepentingan manquf' alaih (penerima wakaf).

\section{Regulasi yang Kurang Mendukung}

Prioritas masalah eksternal yang kedua yaitu regulasi yang kurang mendukung dengan nilai geometric mean sebesar 0.247 . Kurangnya peran dan dukungan dari pemerintah menyebabkan regulasi yang ada saat ini belum mendukung 
sepenuhnya upaya optimalisasi pengelolaan dan pengembangan wakaf di Indonesia.

Menurut para pakar, adanya UU No. 41 Tahun 2004 tentang wakaf perlu diapresiasi. Namun, sampai saat ini aplikasi dari regulasi tersebut belum memberikan dampak yang terasa pada perkembangan praktik wakaf di Indonesia. Regulasi yang ada belum sepenuhnya mendukung upaya optimalisasi pengelolaan wakaf secara produktif, terutama dalam hal pengaturan biaya operasional, penunjukkan nazhir, dan perubahan status naz̧hir menjadi lembaga. Regulasi tersebut juga mengharuskan para nazhir melewati jalur birokrasi yang berbelit, seperti dalam proses izin perubahan tanah untuk mendapatkan sertifikat wakaf. Padahal, alur birokrasi yang cepat dan mudah sangat dibutuhkan guna menunjang kinerja nazhir dalam pengelolaan wakaf.

\section{Peran dan Dukungan Pemerintah yang Kurang}

Prioritas masalah eksternal yang ketiga yaitu kurangnya peran dan dukungan pemerintah dengan nilai geometric mean sebesar 0.209. Sampai saat ini, peran dan dukungan Pemerintah Indonesia masih kurang dirasakan terhadap pengelolaan dan pengembangan wakaf terutama dalam hal fasilitas, regulasi, investasi dan bantuan dana. Hal ini disebabkan belum adanya pemahaman yang komprehensif tentang pentingnya wakaf dan potensinya dalam meningkatkan kesejahteraan masyarakat jika dikelola secara produktif.

Jika merujuk ke negara lain seperti Arab Saudi, maka perkembangan wakaf disana sangat berkembang karena mendapat dukungan penuh dari pemerintahnya, bahkan ada kementerian khusus yang menangani masalah wakaf. Begitupun dengan negara-negara lain yang wakafnya sudah berkembang, hal tersebut tidak lepas dari peran dan dukungan dari pemerintahnya.

Pengelolaan wakaf di Indonesia jauh tertinggal dari beberapa negara muslim dikarenakan kurangnya political will dari pemerintah dalam pengelolaan wakaf. Dalam sisi regulasi, pengelolaan wakaf baru memiliki payung hukumnya di tahun 2004, padahal praktik pengelolaan wakaf telah berlangsung cukup lama. Hal ini menunjukkan bahwa salah satu prioritas masalah dalam pengelolaan wakaf produktif di Indonesia adalah dari aspek pemerintah. ${ }^{15}$

\section{Penunjukan Nazhir oleh Wakif}

Prioritas masalah eksternal yang keempat yaitu penunjukan nazhir oleh wakif dengan nilai geometric mean sebesar 0.183. Mayoritas wakif di Indonesia menunjuk

15 Suwaidi A, "Wakaf dan Penerapannya di Negara Muslim". Jurnal Ekonomi dan Hukum Islam, Vol. 1 No. 2 (2011) h. 14 
nąhir wakaf hanya berdasarkan pada faktor kekerabatan dan kepercayaan pada tokoh agama setempat saja. Hal ini disebabkan oleh kurangnya pemahaman wakif tentang esensi wakaf, sehingga ia menunjuk nąhir bukan berdasarkan kompetensi yang dimiliki untuk mengelola wakaf secara produktif.

Penunjukan naghir oleh wakif juga disebabkan oleh kurangnya regulasi yang mendukung. Dalam UU No. 41 Tahun 2004, tidak dijelaskan secara eksplisit siapa yang berhak mengangkat ną̧bir, hanya saja Pasal 6 PP No.42 Tahun 2006 menunjukkan bahwa penunjukan dan pemberhentian nazhir dapat diusulkan oleh wakif.

Hal ini sesuai dengan survei yang dilakukan oleh Pusat Bahasa dan Budaya UIN Jakarta tahun 2006. Mereka yang menunjuk nazhir sepertiganya adalah masyarakat umum, nazhir yang diangkat oleh wakif $27 \%$, nazhir sebelumnya yang berasal dari keluarga 11\% dan bukan keluarga $6 \%$, pengurus organisasi $12 \%$, dan pemerintah 9\%. Namun, penunjukkan nazhir oleh masyarakat biasanya diwakili wakif, dan juga beberapa kalangan yang dianggap tokoh atau orang berpengaruh di daerah setempat. Selain itu, survei juga menunjukkan bahwa alasan atau pertimbangan pemilihan nazhir $93 \%$ karena masih merupakan sanak saudara atau memiliki hubungan keluarga, 46\% karena dapat dipercaya, dan 30\% karena paham manajemen.

\section{Biaya Operasional yang Minim}

Prioritas masalah eksternal yang kelima yaitu minimnya biaya operasional dengan nilai geometric mean sebesar 0.209. Minimnya biaya operasional untuk keperluan pengelolaan wakaf merupakan masalah yang seringkali dihadapi oleh sebagian besar pengelola (nazhir). Hal tersebut disebabkan kurangnya kerja sama yang dilakukan nazhir dengan para investor muslim.

Menurut salah satu responden, minimnya biaya operasional juga menjadi kendala bagi BWI dalam melakukan pembinaan dan pelatihan naz̧hir. Hal tersebut terjadi karena kurangnya dukungan berupa dana dan fasilitas dari pemerintah, sehingga pembinaan dan pelatihan nazhir belum berjalan efektif.

Hal ini sejalan dengan ungkapan penelitian bahwa kendala yang umum dalam pengelolaan wakaf di Indonesia adalah masalah dana dan masih adanya para pengelola wakaf yang kurang memahami peraturan perundang-undangan yang berkaitan dengan wakaf. Di Indonesia masih sedikit orang yang mewakafkan tanahnya yang produktif, kalau pun ada, untuk mengelolanya 
diperlukan biaya yang banyak dan harus diusahakan. Selain itu minimnya biaya operasional adalah masalah prioritas dalam pengelolaan wakaf produktif. ${ }^{16}$

\section{Aspek Pendekatan Solusi Pengelolaan Wakaf di Indonesia}

Solusi untuk meningkatkan pengelolaan wakaf di Indonesia agar lebih produktif terbagi menjadi dua yaitu solusi internal dan solusi eksternal. Berdasarkan hasil pengolahan data, prioritas utama solusi dalam meningkatkan pengelolaan wakaf adalah solusi internal dengan nilai geometric mean (GMk) sebesar 0.67 , sedangkan prioritas kedua adalah solusi eksternal dengan nilai geometric mean sebesar 0.33. Hasil ini sejalan dengan tingkat prioritas permasalahan yang menunjukkan bahwa prioritas utama adalah masalah internal dan prioritas kedua adalah masalah eksternal. Tingkat prioritas solusi dapat dilihat pada Gambar 6. Hasil perhitungan rater agreement menghasilkan nilai Kendall's Coefficient of Concordance atau W sebesar 0.51 yang menunjukkan bahwa tingkat kesepakatan para pakar (responden) masih cukup tinggi.

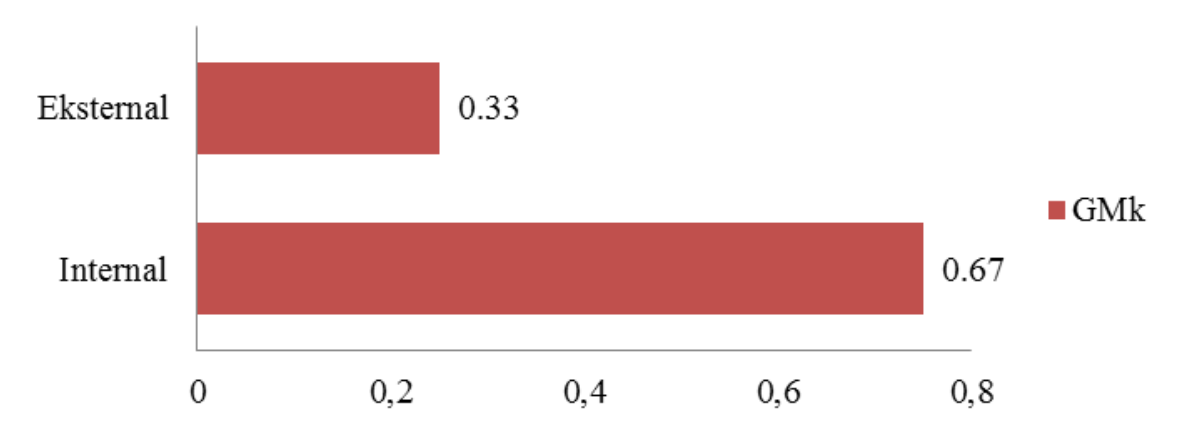

Gambar 6 Tingkat prioritas solusi

\section{Solusi Internal}

Solusi internal yang dimaksud dalam penelitian ini adalah solusi yang dapat diberikan untuk mengatasi masalah internal. Solusi ini terbagi menjadi lima yaitu peningkatan kompetensi nazbir, pembinaan dan pendampingan nazbir, konsolidasi antar nąhir, transformasi nazhir menjadi lembaga, dan meningkatkan insentif nazhir. Berdasarkan hasil pengolahan data, tingkat prioritas solusi internal ini dapat dilihat pada Gambar 7. Prioritas pertama yaitu peningkatan kompetensi nazhir dengan nilai geometric mean sebesar 0.36. Prioritas kedua yaitu pembinaan dan pendampingan nazhir dengan nilai geometric mean sebesar 0.26. Prioritas ketiga yaitu transformasi nazhbir menjadi lembaga dengan nilai geometric

16 Fathurrohman T, Wakaf dan Penanggulangan Kemiskinan Tinjauan Hukum Islam Peraturan Perundang-undangan di Indonesia (Studi Kasus Pengelolaan Wakaf di Kabupaten Bandung), (Jakarta, Universitas Indonesia, 2012) 
mean sebesar 0.18. Prioritas keempat yaitu konsolidasi antar nąhir dengan geometric mean sebesar 0.11. Prioritas kelima yaitu meningkatkan insentif nazhir dengan nilai geometric mean sebesar 0.10. Hasil perhitungan rater agreement menghasilkan nilai Kendall's Coefficient of Concordance atau W sebesar 0.76 yang menunjukkan bahwa tingkat kesepakatan para pakar (responden) cukup tinggi.

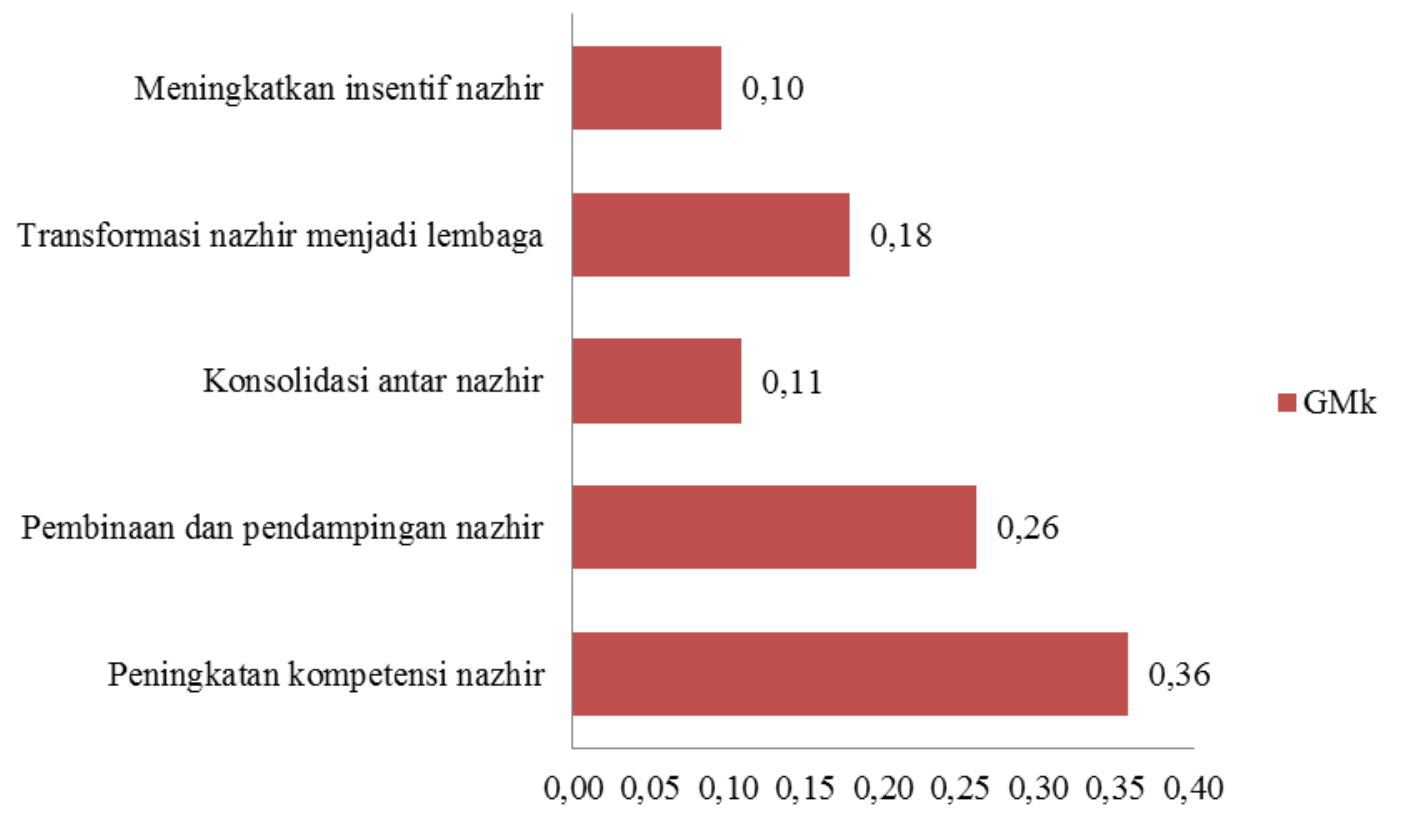

Gambar 7 Tingkat prioritas solusi internal

\section{Peningkatan Kompetensi Nazhir}

Prioritas solusi internal yang pertama yaitu peningkatan kompetensi naz̧bir dengan nilai geometric mean sebesar 0.36. Peningkatan kompetensi ini perlu dilakukan karena mayoritas naz̧bir belum memiliki kompetensi yang memadai dalam mengelola wakaf terutama dalam hal kompetensi bisnis.

Berdasarkan wawancara, dalam mengelola kekayaan umat tidaklah mudah. Para pengelola wakaf harus mulai memperbaiki diri menerima amanah Allah dalam hal ini terpilih sebagai nazhir, mesti didampingi dengan kemampuan mengelola. Salah satu perbedaan lembaga wakaf dengan lembaga sosial lainnya adalah adanya mekanisme mengelola aset, sehingga disamping memiliki 
kompetensi dalam hal agama, nazhir juga harus mempunyai kompetensi dalam hal bisnis. ${ }^{17}$

\section{Pembinaan dan Pendampingan Nazhir}

Prioritas solusi internal yang kedua yaitu pembinaan dan pendampingan nazhir dengan nilai geometric mean sebesar 0.26 . Solusi ini perlu dilakukan karena tugas dan tanggung jawab nazhir yang cukup berat, namun tidak didampingi dengan kompetensi yang memadai. Selain itu, dalam peraturan perundang-undangan wakaf telah dijelaskan bahwa nąhir berhak mendapatkan pembinaan dari BWI untuk menunjang kinerjanya agar bekerja lebih profesional, akan tetapi belum berjalan efektif. Dengan adanya pembinaan dan pendampingan nazhir yang intensif diharapkan kompetensi dan profesionalitas para naæhir meningkat sehingga bisa mengelola dan mengembangkan wakaf dengan lebih optimal dan produktif.

\section{Transformasi Nazhir menjadi Lembaga}

Prioritas solusi internal yang ketiga yaitu transformasi nazhir menjadi lembaga dengan nilai geometric mean sebesar 0.18. Solusi ini perlu dilakukan karena nazhir perorangan meskipun diakui oleh undang-undang wakaf, masih memiliki banyak sekali kelemahan. Nazhbir perorangan biasanya tidak memiliki struktur kepengurusan yang jelas, tidak memiliki kekuatan hukum seperti akta notaris, dan kurang memiliki akuntabilitas.

Berdasarkan wawancara dengan para pakar, mereka berpandangan bahwa nazhir berbasis lembaga lebih memiliki peluang berkembang daripada nazbir perorangan dikarenakan struktur manajemennya yang sudah modern. Solusi yang mungkin dapat dilakukan agar pengelolaan wakaf lebih optimal adalah dengan mentransformasikan diri menjadi ną̧ ir berbasis lembaga seperti nazh hir organisasi atau badan hukum. Jika belum memungkinkan bertransformasi menjadi lembaga, maka setidaknya nazhir perorangan harus mulai mengadopsi manajemen modern agar aset wakafnya dapat lebih berkembang. Urgensi mengarahkan nazhir perorangan kepada nazhir berbasis lembaga karena nazhir berbasis lembaga telah mengaplikasikan manajemen wakaf dengan lebih baik dibandingkan dengan nazhir perorangan.

\section{Konsolidasi antar Nazhir}

Prioritas solusi internal yang keempat yaitu konsolidasi antar ną̧ir dengan nilai geometric mean sebesar 0.11. Menurut salah satu responden, solusi ini perlu

17 Wawancara dengan Nanda Putera Setiawan, Direktur Wakaf Al Azhar di Jakarta, 16 Agustus 2017 
dilakukan karena tidak semua nąhir memiliki kompetensi yang sama dalam mengelola wakaf, bahkan ada yang sama sekali belum berkompeten. Dengan adanya konsolidasi antar nazhir, diharapkan bisa menjadi sarana untuk saling bertukar pikiran dalam menghadapi permasalahan wakaf, saling sharing informasi dan keahlian yang dimiliki, serta saling menguatkan satu sama lain agar terus berjuang bersama mengelola kekayaan umat.

\section{Meningkatkan Insentif Nazhir}

Prioritas solusi internal yang kelima yaitu meningkatkan insentif nazhir dengan nilai geometric mean sebesar 0.10 . Solusi ini perlu dilakukan agar semakin banyak orang tertarik menjadi nazhir dan bekerja lebih profesional. Meski insentif bukan menjadi prioritas utama karena orientasi akhirat harus lebih penting bagi nazhir, hal tersebut tidak menafikan bahwa nazhir akan terdorong lebih bersemangat dan bekerja lebih profesional ketika mendapatkan insentif yang layak sesuai dengan tanggung jawab dan tugas mereka yang cukup berat dalam mengelola wakaf. Peningkatan insentif bagi nazhir mendorong totalitas nazhir dalam mengelola aset wakaf, sehingga profesionalisme nazhir akan terwujud dengan sendirinya. ${ }^{18}$

\section{Solusi Eksternal}

Solusi eksternal yang dimaksud dalam penelitian ini adalah solusi yang dapat diberikan untuk mengatasi masalah eksternal. Solusi ini terbagi menjadi lima yaitu perbaikan sistem rekrutmen nazhir, sosialisasi dan edukasi kepada wakif/calon wakif, optimalisasi fungsi dan peran BWI, revisi regulasi yang kurang mendukung, dan meningkatkan biaya operasional. Berdasarkan hasil pengolahan data, tingkat prioritas solusi eksternal ini dapat dilihat pada Gambar 8. Prioritas pertama yaitu optimalisasi fungsi dan peran BWI dengan nilai geometric mean sebesar 0.27. Prioritas kedua yaitu revisi regulasi yang kurang mendukung dengan nilai geometric mean sebesar 0.24. Prioritas ketiga yaitu sosialisasi dan edukasi kepada wakif/calon wakif dengan nilai geometric mean sebesar 0.22. Prioritas keempat yaitu perbaikan sistem rekrutmen nazhir dengan nilai geometric mean sebesar 0.17. Prioritas kelima yaitu meningkatkan biaya operasional dengan nilai geometric mean sebesar 0.10. Perhitungan rater agreement menghasilkan nilai Kendall's Coefficient of Concordance atau W sebesar 0.72, yang menunjukkan bahwa tingkat kesepakatan para pakar (responden) cukup tinggi.

${ }^{18}$ Huda N, Anggraini D, Rini N, Hudori, Mardoni Y, “Akuntabilitas sebagai Solusi Pengelolaan Wakaf'. Jurnal Akuntansi Multiparadigma, Vol. 5, No. 3, (2014) h. 485-497 


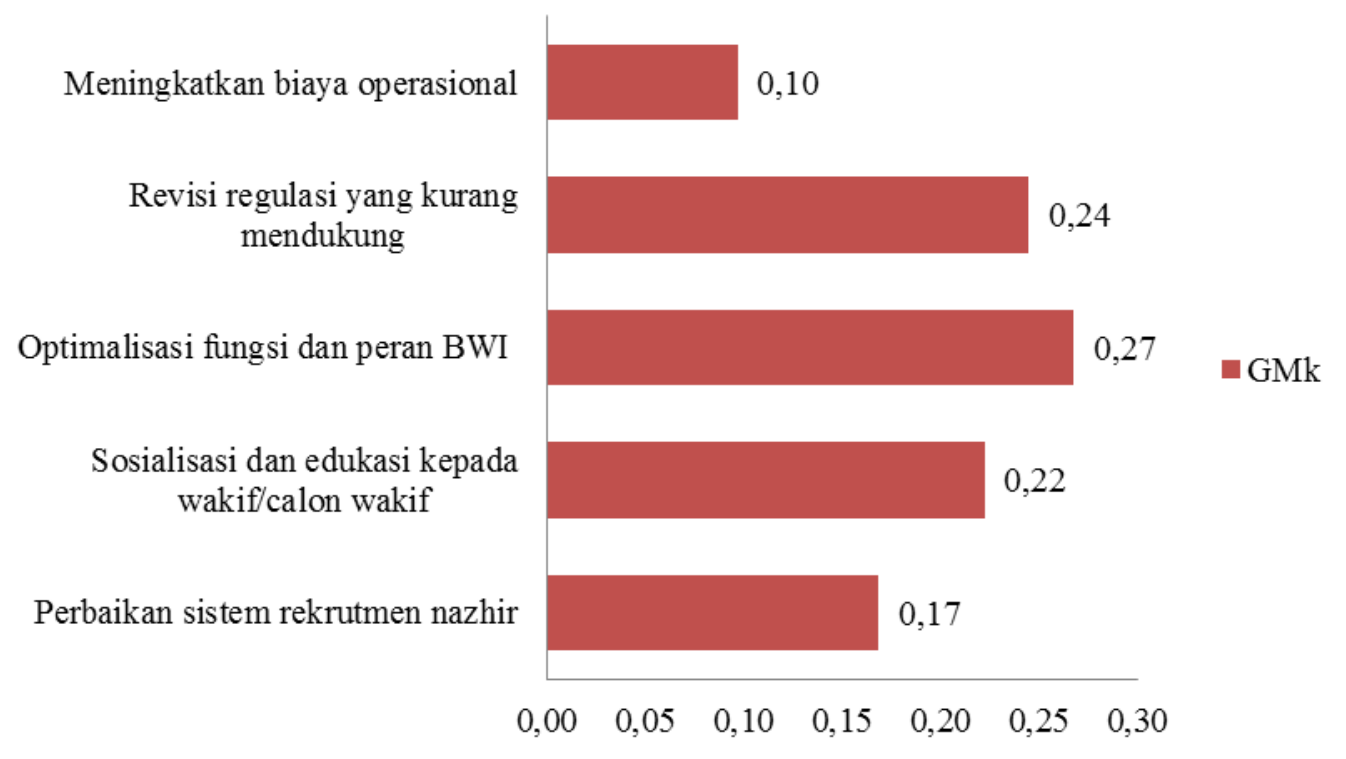

Gambar 8 Tingkat prioritas solusi eksternal

\section{Optimalisasi Fungsi Badan Wakaf Indonesia (BWI)}

Prioritas solusi eksternal yang pertama yaitu optimalisasi fungsi dan peran BWI dengan nilai geometric mean sebesar 0.27. Badan Wakaf Indonesia (BWI) merupakan lembaga independen yang mempunyai tanggung jawab besar dalam memajukan dan mengembangkan perwakafan di Indonesia yang telah diatur dalam undang-undang, namun sampai saat ini belum bekerja secara efektif, sehingga perlu dioptimalisasikan kembali fungsi dan peranannya. Solusi ini dapat berjalan dengan baik, ketika mendapat dukungan penuh dari pemerintah berupa fasilitas dan juga biaya operasional.

Fungsi dan peran BWI sangat penting dalam hal pembinaan dan pelatihan yang intensif bagi nazhir. Ketika pembinaan dapat dilakukan dengan baik dan efektif maka kompetensi nazhir akan meningkat, sehingga pengelolaan wakaf dapat dilakukan lebih optimal dan produktif. Peran BWI ini sangat memengaruhi kualitas nazhir sebagai pengelola wakaf, karena sesuai dengan Pasal 49 Undang-Undang Nomor 41 Tahun 2004 BWI memiliki tugas dalam pembinaan terhadap nąhir dalam mengelola dan mengembangkan wakaf. ${ }^{19}$

19 Hamzah Z, Analisis Faktor-Faktor yang Memengarubi Pengelolaan Wakaf di Kabupaten Bogor, (Bogor: 2016) h. 34-35 


\section{Revisi Regulasi yang Kurang Mendukung}

Prioritas solusi eksternal yang kedua yaitu revisi regulasi yang kurang mendukung dengan nilai geometric mean sebesar 0.24. Kehadiran UU No.41 Tahun 2004 dan PP No.42 Tahun 2006 perlu diapresiasi dalam upaya pengembangan wakaf di Indonesia. Namun, masih terdapat beberapa kelemahan terutama terkait dengan petunjuk pengelolaan wakaf yang produktif, biaya operasional, penunjukkan naz̧bir, dan perubahan nazhir menjadi lembaga.

Selain itu, regulasi yang ada mengharuskan para nazhir melewati jalur birokrasi yang berbelit. Padahal, alur birokrasi yang cepat dan mudah sangat dibutuhkan guna menunjang kinerja nazhir dalam pengelolaan wakaf. Oleh karena itu, perbaikan atau revisi regulasi yang kurang mendukung ini diharapkan dapat menjadi solusi atas permasalahan tersebut, sehingga birokrasi perwakafan di Indonesia dapat berjalan sesuai dengan rambu-rambu yang telah ditetapkan.

\section{Sosialisasi dan Edukasi kepada Wakif atau Calon Wakif}

Prioritas solusi eksternal yang ketiga yaitu sosialisasi dan edukasi kepada wakif atau calon wakif dengan nilai geometric mean sebesar 0.22. Solusi ini perlu dilakukan karena mayoritas masyarakat atau wakif mempunyai pemahaman yang masih tradisional tentang wakaf. Mereka hanya memahami bahwa wakaf sebatas sarana ibadah atau kuburan dan belum memiliki pola pikir wakaf yang produktif, sehingga perlu diberikan pemahaman dengan melalui sosialisasi dan edukasi secara komprehensif, baik mengenai peraturan dalam islam maupun peraturan perundang-undangan. Ketika para wakif telah memiliki pemahaman tentang wakaf secara komprehensif, maka mereka akan lebih cenderung memilih atau menunjuk nazhir yang sudah profesional dan kompeten, sehingga lebih mudah mengelola wakaf secara produktif.

\section{Perbaikan Sistem Rekrutmen Nazhir}

Prioritas solusi eksternal yang keempat yaitu perbaikan sistem rekrutmen naz̧hir dengan nilai geometric mean sebesar 0.17. Mayoritas nazhir wakaf yang ditunjuk oleh masyarakat atau wakif hanya didasarkan pada hubungan kekeluargaan atau aspek ketokohan, bukan pada aspek profesionalisme atau kemampuan mengelola. Hal tersebut menjadikan banyak aset-aset wakaf yang akhirnya tidak terurus atau terkelola dengan baik. Oleh karena itu, perbaikan sistem rekrutmen nazhir diharapkan dapat memperbaiki kualitas nąhir sehingga pengelolaan wakaf menjadi lebih optimal. Perbaikan sistem rekrutmen nazhir ini dapat dilakukan dengan adanya standarisasi atau sertifikasi nazhir dan juga bisa dilakukan melalui perbaikan regulasi. 


\section{Meningkatkan Biaya Operasional}

Prioritas solusi eksternal yang kelima yaitu meningkatkan biaya operasional dengan geometric mean sebesar 0.10. Solusi ini perlu dilakukan karena biaya operasional merupakan salah satu masalah yang dikeluhkan oleh para nazhir dalam mengelola wakaf dan juga BWI untuk keperluan pembinaan nazhir. Peningkatan biaya operasional ini sangat memerlukan dukungan dan bantuan dari pemerintah, baik melalui regulasi ataupun bantuan dana secara langsung. Selain itu, biaya operasional juga bisa didapatkan melalui sumbangan dari masyarakat ataupun bermitra dengan para investor muslim.

Pemerintah memiliki peran sebagai fasilitator dan juga memiliki tugas penting terhadap pengelolaan wakaf produktif, yaitu memberikan dua bentuk pengawasan yang layak seperti pengawasan administrasi dan keuangan. Meningkatkan biaya operasional merupakan solusi prioritas dalam pengelolaan wakaf produktif di Indonesia. ${ }^{20}$

\section{Perumusan Strategi Optimal berdasarkan Pendekatan Masalah dan Solusi}

Strategi yang dirumuskan berdasarkan masalah dan solusi yang ada untuk meningkatkan pengelolaan wakaf di Indonesia agar lebih produktif terbagi menjadi tiga yaitu sinergi dan kolaborasi antar lembaga atau instansi terkait, sosialisasi dan edukasi wakaf secara komprehensif kepada semua elemen, serta optimalisasi sumber daya yang sudah ada. Hasil pengolahan data menunjukkan bahwa prioritas utama strategi adalah melakukan sosialisasi dan edukasi wakaf secara komprehensif kepada semua elemen dengan nilai geometric mean sebesar 0.5 , sedangkan prioritas kedua terbagi menjadi dua aspek karena nilai geometric mean yang sama yaitu optimalisasi sumber daya yang sudah ada dan melakukan sinergi serta kolaborasi antar lembaga/instansi terkait dengan nilai geometric mean sebesar 0.25. Perhitungan rater agreement menghasilkan nilai Kendall's Coefficient of Concordance atau W sebesar 0.55 yang menunjukkan bahwa tingkat kesepakatan para pakar (responden) cukup tinggi. Tingkat prioritas strategi ini dapat dilihat pada Gambar 9.

20 Qahaf M, Manajemen Wakaf Produktif, (Jakarta: Pustaka Al-Kautsar Group, 2005) h. 43-46 


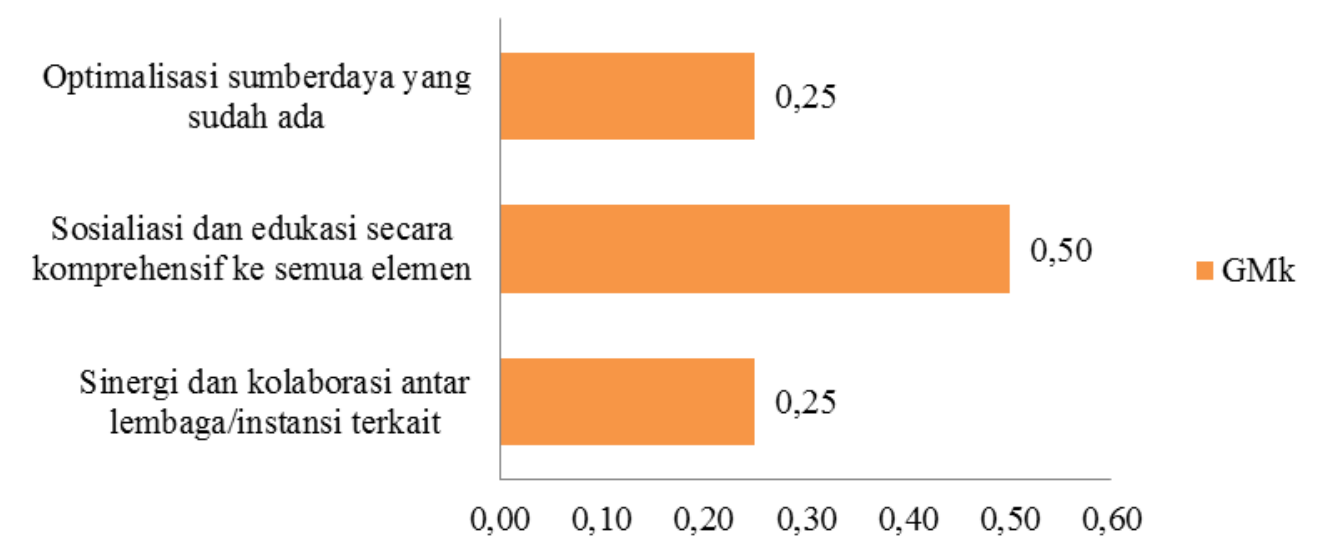

Gambar 9 Tingkat prioritas strategi

Prioritas strategi yang pertama adalah sosialisasi dan edukasi secara komprehensif kepada semua elemen dengan nilai geometric mean sebesar 0.5. Strategi ini perlu dilakukan karena ilmu atau pemahaman merupakan kunci dalam melakukan suatu amalan atau pekerjaan. Mayoritas masalah yang muncul disebabkan oleh kurangnya pemahaman tentang wakaf dari berbagai pihak, baik nąhir, wakif, pemerintah, maupun masyarakat. Selain itu, solusi pun bisa dilaksanakan dengan baik jika semua pihak memiliki pemahaman yang sama tentang wakaf. Alasan tersebut menjadikan sosialisasi dan edukasi sangat penting digencarkan kembali untuk menyamakan pemahaman dan persepsi antar pihak, sehingga lebih mudah bekerja sama dalam mengelola dan mengembangkan wakaf di Indonesia.

Prioritas strategi yang kedua terbagi menjadi dua aspek yaitu sinergi dan kolaborasi antar lembaga serta optimalisasi sumber daya yang sudah ada, dengan nilai geometric mean yang sama sebesar 0.25 . Permasalahan wakaf yang begitu kompleks tidak dapat diatasi oleh satu pihak saja. Hal tersebut memerlukan sinergi dan kolaborasi antar lembaga-lembaga yang terkait dengan wakaf seperti BWI, Kementerian Agama, Lembaga Keuangan Syariah, Lembaga Zakat, Badan Pertanahan Nasional, Majelis Ulama Indonesia, dan instansi lainnya untuk merumuskan pembagian peran, sehingga tidak terjadi tumpang tindih atau penumpukan tugas. Selain itu, optimalisasi sumber daya yang sudah ada juga perlu dilakukan karena Indonesia memiliki potensi wakaf dan sumber daya yang sangat besar, baik sumber daya manusia maupun sumber daya lahannya. Sumber daya tersebut harus dimanfaatkan seoptimal mungkin, sehingga diharapkan dapat meningkatkan pengelolaan dan pengembangan wakaf di Indonesia dan hasilnya dapat dirasakan untuk kesejahteraan umum. 


\section{PENUTUP}

Hasil penelitian terbukti bahwa masalah internal pengelolaan wakaf yang paling prioritas adalah kurangnya kompetensi pengelola wakaf atau nąhir dengan nilai geometric mean (GMk) sebesar 0.33 dan profesionalisme nazhir dengan nilai GMk sebesar 0.24 . Sedangkan kurangnya pemahaman wakif menjadi prioritas masalah eksternal dengan nilai GMk sebesar 0.25 dan regulasi yang kurang mendukung dengan nilai GMk sebesar 0.247.

Prioritas aspek solusi internal manajemen wakaf di Indonesia pada hasil analisis adalah peningkatan kompetensi nazhir dengan nilai GMk sebesar 0.36 serta pembinaan dan pendampingan nazhbir dengan nilai GMk 0.26. Disamping itu, prioritas solusi eksternal adalah optimalisasi fungsi BWI dengan nilai GMk sebesar 0.27 dan revisi regulasi yang kurang mendukung dengan nilai GMk sebesar 0.24.

Berdasarkan masalah dan solusi tersebut, terdapat tiga strategi yang dapat menjadi alternatif, yaitu sinergi dan kolaborasi antar lembaga, sosialisasi dan edukasi secara komprehensif kepada semua elemen, serta optimalisasi sumberdaya yang sudah ada. Namun, yang menjadi prioritas paling penting dari alternatif strategi adalah dengan melakukan sosialisasi dan edukasi secara komprehensif kepada semua elemen dengan nilai GMk sebesar 0.5.

Saran yang dapat diberikan kepada pembuat kebijakan dan praktisi wakaf berdasarkan hasil analisis penelitian ini adalah:

1. Masalah utama bagi para nazhir adalah kompetensi dan profesionalitas. Oleh karena itu, nazhir harus terus mendapatkan pembinaan dan pendampingan serta pelatihan yang intensif agar mampu mengelola wakaf dengan lebih baik. Pembinaan dan pelatihan tersebut dapat dilakukan melalui pendidikan formal atau informal serta pembinaan fisik, spiritual maupun mental.

2. BWI memiliki tugas melakukan pembinaan terhadap nazhir sebagaimana telah diatur dalam perundang-undangan, sedangkan fungsi lembaga tersebut realitanya belum optimal, sehingga perlu adanya revitalisasi dan optimalisasi fungsi dan peran dari BWI. Salah satu cara agar fungsi dan peran BWI lebih optimal adalah meningkatkan kualitas sumber daya manusia yang ada di dalamnya. Selain itu, peran dan dukungan pemerintah baik melalui bantuan dana, fasilitas atau regulasi akan sangat berarti.

3. Pemahaman wakif yang kurang juga menjadi masalah yang menyebabkan pengelolaan wakaf belum optimal. Oleh karena itu, sosialisasi yang menyeluruh tentang wakaf dan peraturannya, baik dalam islam maupun perundang-undangan harus terus digencarkan. 
4. Pelaksanaan sosialisasi dan edukasi wakaf harus tetap dilakukan dari waktu ke waktu kepada semua elemen secara komprehensif karena masih banyak pihak dari nazhir, wakif, pemerintah, maupun masyarakat umum yang belum memahami wakaf. Program ini memerlukan kerja sama dan dukungan dari pemerintah, para ulama, akademisi, dan praktisi di bidang wakaf.

5. Optimalisasi sumber daya yang ada, baik sumber daya manusia maupun sumber daya lahan. Hal tersebut dapat dilakukan dengan mendata terlebih dahulu seluruh aset wakaf dan juga data nazhir secara akurat. Selain itu, aset wakaf yang sudah tidak memberikan manfaat dapat dioptimalkan kembali dengan melakukan pertukaran harta wakaf (istibdal) kepada aset wakaf yang dapat memberikan maslahat yang lebih besar.

6. Sinergisasi dan kolaborasi dengan berbagai pihak atau instansi yang terkait dengan wakaf seperti BWI, Kementerian Agama, Lembaga Zakat, MUI, BPN dan Lembaga Keuangan Syariah, sehingga langkah-langkah dalam pengembangan wakaf dapat berjalan baik dan hasilnya dapat dirasakan untuk kesejahteraan umat.

7. Penelitian ini menunjukkan bahwa prioritas strategi yang utama adalah dengan melakukan sosialisasi dan edukasi wakaf. Oleh karena itu, perlu adanya penelitian lebih lanjut untuk mencari strategi yang tepat dan efektif dalam melakukan sosialisasi dan edukasi wakaf kepada semua elemen masyarakat agar perkembangan wakaf di Indonesia lebih baik.

\section{DAFTAR PUSTAKA}

[PP] Peraturan Pemerintah Republik Indonesia Nomor 28 Tahun 1977 Tentang Perwakafan Tanah Milik.

[PP] Peraturan Pemerintah Republik Indonesia Nomor 42 Tahun 2006 Tentang Pelaksanaan Undang-Undang Republik Indonesia Nomor 41 Tahun 2004.

[UU] Undang-Undang Republik Indonesia Nomor 41 Tahun 2004 Tentang Wakaf.

Al-Kabisi MAA, Hukum Wakaf, (Jakarta: Dompet Dhuafa Republika, 2004).

Ascarya, Analytic Network Process (ANP) Pendekatan Baru Studi Kualitatif, (Jakarta: Seminar Internasional Program Magister Akuntansi Fakultas Ekonomi, 2005).

Aziz M, "Kompetensi Ną̧hir dalam Mengelola Wakaf Produktif'. Jurnal AlAwqaf, Vol. 7, No. 1 (2014). 
Badan Wakaf Indonesia, Sejarah dan Perkembangan Wakaf, (Jakarta: BWI Indonesia, 2007).

David FR, Manajemen Strategis Konsep Edisi ke-10, (Jakarta: Salemba Empat, 2006).

Djamil F, Standarisasi dan Profesionalisme Nazhir di Indonesia, Jakarta: BWI Indonesia, 2011).

Fathurrohman T, "Wakaf dan Penanggulangan Kemiskinan Tinjauan Hukum Islam Peraturan Perundang-undangan di Indonesia (Studi Kasus Pengelolaan Wakaf di Kabupaten Bandung)", (Jakarta: Universitas Indonesia, 2012).

Hamzah Z, "Analisis Faktor-Faktor yang Memengaruhi Pengelolaan Wakaf di Kabupaten Bogor”, (Bogor: Institut Pertanian Bogor, 2016).

Hasanah U, Inovasi Pengembangan Wakaf di Berbagai Negara, (Jakarta: BWI Indonesia, 2008).

Hasanah U, Potensi Wakaf Uang untuk Pembangunan Perumahan Rakyat (Jakarta: BWI Indonesia, 2010).

Huda N, Anggraini D, Rini N, Hudori, Mardoni Y, “Akuntabilitas sebagai Solusi Pengelolaan Wakaf'. Jurnal Akuntansi Multiparadigma. Vol. 5, No. 3 (2014).

Karim SA, Contemporary Waqf Administration and Development in Singapore. The Singapore International Waqf Conference. (pp. 2-10), Singapore, SGN: 2007.

Kementerian Agama RI, Al-Qur'an dan Terjemahannya, (Bekasi: Cipta Bagus Sagara, 2012).

Khadijah, Faktor-Faktor yang Memengarubi Tingkat Penghimpunan Wakaf Uang di Indonesia, (Bogor: Institut Pertanian Bogor, 2016).

Nafis C, Menggagas Nazhir Wakaf Profesional, http://www.bwi.or.id. [Internet], diakses pada pada 25 Februari 2017 pukul 17.00 WIB.

Najib TA, al-Makassary R, Wakaf, Tuhan, dan Agenda Kemanusiaan, (Jakarta: Center for the Study of Religion and Culture (CSRC), 2006).

Nasution ME, Hasanah U, Wakaf Tunai Inovasi Finansial Islam, Peluang dan dalam Mewujudkan Kesejabteraan Umat, (Jakarta: PKT'TI-UI, 2005).

Putri KS, Pembinaan Naz̧bir Wakaf di Kementerian Agama Kota Padang dan Badan Wakaf Indonesia Sumatera Barat (Studi Implementasi Pasal 13 Undang-Undang No.41 Tabun 2004 Tentang Wakaf, (Yogyakarta: UIN Sunan Kalijaga, 2016). 
28 |Al-Falah: Journal of Islamic Economics, Vol.3, No.1, 2018

Qahaf M, Manajemen Wakaf Produktif. Jakarta: Pustaka Al-Kautsar Group, 2005).

Rozalinda, Manajemen Wakaf Produktif. (Jakarta: Rajawali Pers, 2015).

Saaty TL, Fundamentals of the Analytic Network Process, Tokyo, Jepang, 1999.

Saaty TL, Vargas LG, Decision Making with the Analytic Network Process: Economic, Political, Social and Technological Applications with Benefits, Opportunities, Costs and Risks, (Pittsburgh: Springer, 2006).

Siagian SP, Manajemen Stratejik. (Jakarta: PT Bumi Aksara, 2008).

Suwaidi A, "Wakaf dan Penerapannya di Negara Muslim". Jurnal Ekonomi dan Hukum Islam, Vol. 1. No. 2 (2011).

Wadud AMA, Solusi Permasalahan Wakaf Produktif di Indonesia Pendekatan Modifikasi Analytic Network Process, (Depok: Universitas Indonesia, 2013)

Wheelen TL, Hunger JD, Strategic Management and Business Policy, Ninth Edition, (New Jersey: Pearson Education, Inc, 2004) 